\title{
44th ASMS Conference on Mass Spectrometry \& Allied Topics
}

May 12 - 16, 1996 - Portland, Oregon • For information call ASMS (505) 989-4517

SUN
PM

MON

AM

PM

TUES

AM

PM Oral Session: Frontiers in Isotope Ratio Measurements

\section{Registration}

ASMS Meeting: Welcome, Reports, Planning

MS Tutorials

Welcome Mixer

Plenary Lecture: Carl E. Wieman, JILA and Department of Physics, University of Colorado Oral Session: Electrospray and MALDI of Large Molecules

Oral Session: Emerging Methods for Biomedical Applications

Oral Session: History of Various Mass Separation Techniques

Oral Session: Reactions of Gas Phase Ions

Oral Session: Moving Mass Spec Out of the Lab: In-situ, On-line and Portable MS Applications

Oral Session: New Developments and Applications in Inorganic Mass Spectrometry

WORKSHOPS

POSTERS

Oral Sessions continued

Plenary Lecture: Alan G. Marshall, National High Magnetic Field Laboratory, Florida State

University

Oral Session: Electrospray and MALDI of Small Molecules

Oral Session: Mass Spectrometry in Pharmacology and Toxicology

Oral Session: TOF Methods for DNA Sequencing

Oral Session: Host-Guest Interactions

Oral Session: Direct Sampling Mass Spectrometry: Fundamentals and Applications

WORKSHOPS

POSTERS

Oral Sessions continued

\section{WED}

AM

Plenary Lecture: Catherine C. Fenselau, Department of Chemistry and Biochemistry, University of Maryland Baltimore County

Oral Session: Fundamentals of MALDI

Oral Session: MS Based Strategies for Characterizing Biomolecule-Ligand Interactions

Oral Session: Ion Traps: Fundamentals and Applications

Oral Session: Ion Structure and Energetics

Oral Session: Mass Spectrometry and DNA Adducts: Environmental Carcinogens? Human

$$
\text { Dosimetry? }
$$

PM WORKSHOPS

POSTERS

Oral Sessions continued

THURS

$\mathbf{A M}$

Plenary Lecture: Jean Clottes, International Commiltee on Rock Art, Paris, France

Oral Session: Fundamentals of Electrospray

Oral Session: Cellular Recognition and Signal Transduction

Oral Session: Fast Separations/Mass Spectrometry

Oral Session: Fourier Transform Mass Spectrometry

Oral Session: Environmental Mass Spectrometry

PM

Oral Session: Mass Spectrometric Characterization of Synthetic Polymers

WORKSHOPS

POSTERS

Oral Sessions continued

Evening Event: Award Presentations, Plenary Lecture and Reception: Recipient of the 1996 ASMS

Award for a Distinguished Contribution in Mass Spectrometry

Also
May
$11-12$

ASMS Short Courses immediately preceding the conference

Introduction to Interpretation of Mass Spectra - LC/MS: The Art and the Practice

Practical MS/MS - Introduction to Ion Optics and SIMION

11-12 


\section{ASMS ADVANCE CONFERENCE REGISTRATION FORM}

Please photocopy this form and send to ASMS at the address below.

MEMBER RATES: To register as a member, 1996 dues must have been paid by March 30, $1996 . \quad$ No advance registrations at the member rate will be accepted without PRIOR dues payment.

STUDENTS: A person working in a degree program up to and including the Ph.D. may register at the student rate. Please supply the information requested of student registrants. Student registration is NOT intended for those taking courses in addition to full-time employment.

CANCELLATIONS: To cover the cost of handling and processing, $\$ 20$ will be deducted from the total refund for cancellations. Requests for refunds must be postmarked on or before May 10, 1996.

ON-SITE REGISTRATION: On-site registration fees are $\$ 40$ higher than advance registration: Members - $\$ 180$, Student Members - \$115, Non-Members - \$270, and Student Non-Members - \$160.

DEADLINE: The deadline for advance registration is April 12, 1996. Those who have not registered by April 12, may register on-site at the Oregon Convention Center starting Sunday, May 12 from 1-7 pm.

NAME

COMPANY/INSTITUTION

ADDRESS

CITY, STATE, ZIP, COUNTRY

OFFICE PHONE/FAX
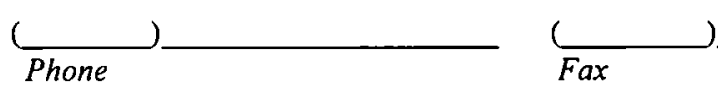

E-MAIL

CONFERENCE REGISTRATION: (Check one) Note: For advance registration only. For on-site registration, see above. If you have not paid 1996 dues, you must register at the non-member rate. DO NOT INCLUDE MEMBERSHIP DUES PAYMENT OR SHORT COURSE REGISTRATION WITH THIS CONFERENCE REGISTRATION.
$\square$ Emeritus
(no charge)
$\square$ ASMS Member, $\$ 140$
$\square$ Non-Member, $\$ 230$

STUDENTS: Please supply name of major professor. $\square$ ASMS Student Member, $\$ 75$

$\square$ Student Non-Member, $\$ 120$

Name University

NON-MEMBERS ONLY: If you are registering as a non-member, you may obtain all the benefits of membership through March 30, 1997 by paying an additional \$20. This will entitle you to 12 issues of the Journal of the American Society for Mass Spectrometry, plus eligibility to vote in the 1997 ASMS election. This membership status will not apply to 1997 conference registration.

Enter \$20 to become a 1996 ASMS Member \$

\section{COMPANION REGISTRATION, $\$ 25$ per person Companion Registration Amount $\$$}

Name for companion badge, City, State

\section{TOTAL AMOUNT S}

$\square$ I have enclosed check or money order payable to ASMS for the Total Amount. Purchase orders cannot be accepted. Checks must be payable in U.S. dollars and through a U.S. bank.

$\square$ Please charge the Total Amount to my VISA or MasterCard. Sorry, no other cards accepted.

VISA No.

Signature MasterCard No.

Send this form with payment to: ASMS Conference, 1201 Don Diego Avenue, Santa Fe, NM 87505 Fax: (505) 989-1073 (Faxed registrations must include credit card information.) Must be received by April 12, 1996 